May 1999 • NREL/CP-550-26642

\title{
Solar Two Performance Evaluation
}

\section{Preprint prepared for IECEC}

\author{
Mary Jane Hale
}

To Be Presented at the Intersociety Energy Conversion Engineering Conference

Vancouver, British Columbia, Canada

August 1-5, 1999
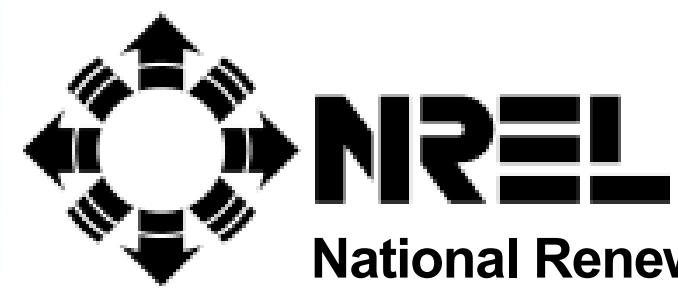

National Renewable Energy Laboratory

1617 Cole Boulevard

Golden, Colorado 80401-3393

NREL is a U.S. Department of Energy Laboratory

Operated by Midwest Research Institute $\bullet$ Battelle $\bullet$ Bechtel

Contract No. DE-AC36-98-G010337 


\section{NOTICE}

This report was prepared as an account of work sponsored by an agency of the United States government. Neither the United States government nor any agency thereof, nor any of their employees, makes any warranty, express or implied, or assumes any legal liability or responsibility for the accuracy, completeness, or usefulness of any information, apparatus, product, or process disclosed, or represents that its use would not infringe privately owned rights. Reference herein to any specific commercial product, process, or service by trade name, trademark, manufacturer, or otherwise does not necessarily constitute or imply its endorsement, recommendation, or favoring by the United States government or any agency thereof. The views and opinions of authors expressed herein do not necessarily state or reflect those of the United States government or any agency thereof.

Available to DOE and DOE contractors from:

Office of Scientific and Technical Information (OSTI)

P.O. Box 62

Oak Ridge, TN 37831

Prices available by calling 423-576-8401

Available to the public from:

National Technical Information Service (NTIS)

U.S. Department of Commerce

5285 Port Royal Road

Springfield, VA 22161

$703-605-6000$ or $800-553-6847$

or

DOE Information Bridge

http://www.doe.gov/bridge/home.html

Printed on paper containing at least $50 \%$ wastepaper, including $20 \%$ postconsumer waste 


\title{
Solar Two Performance Evaluation
}

\author{
Mary Jane Hale \\ National Renewable Energy Laboratory
}

\section{ABSTRACT}

Solar Two was a 10-MWe prototype central receiver plant east of Barstow, California. Solar Two, which was sponsored by a consortium of utilities and industry in partnership with the U.S. Department of Energy, began regular electricity production in February 1997 and completed its last day of regular electricity production in March 1999. This paper presents preliminary results from the most recent Solar Two performance evaluation.

The primary aspect of the performance evaluation is the lost-electricity analysis. This analysis compares the actual generation with the generation predicted by the Solar Two model. (SOLERGY, a Sandia National Laboratories-developed computer program designed to simulate the operation and power output of a solar central receiver power plant, is the code used to model Solar Two.) The difference between the predicted and the actual generation (i.e., the lost electricity) is broken down into the different efficiency and availability categories responsible for the loss. Having the losses broken down by system and in terms of electricity is useful for understanding and improving the plant's performance; it provides a tool for determining the best operating procedures for plant performance and for indicating where operation and maintenance resources should be focused for the best performance payback. This paper briefly describes the methodology behind the lost-electricity analysis.

\section{INTRODUCTION}

Solar Two was a 10-MWe molten-salt central-receiver plant located near Barstow, California. In a molten-salt central-receiver plant, a field of sun-tracking mirrors called heliostats reflects the sun's energy onto a cylindrical receiver that is mounted on a tower. Molten salt is the heat transfer fluid, collecting energy as it flows through the receiver, and is heated from $290^{\circ} \mathrm{C}$ to $565^{\circ} \mathrm{C}$ $\left(550^{\circ} \mathrm{F}\right.$ to $\left.1050^{\circ} \mathrm{C}\right)$. From the receiver, the hot salt flows to thermal storage where it is then sent through a steam generation system (SGS) that powers a turbine and generator to produce electricity. After producing steam in the SGS, the "cool" salt returns to the "cold" side of the

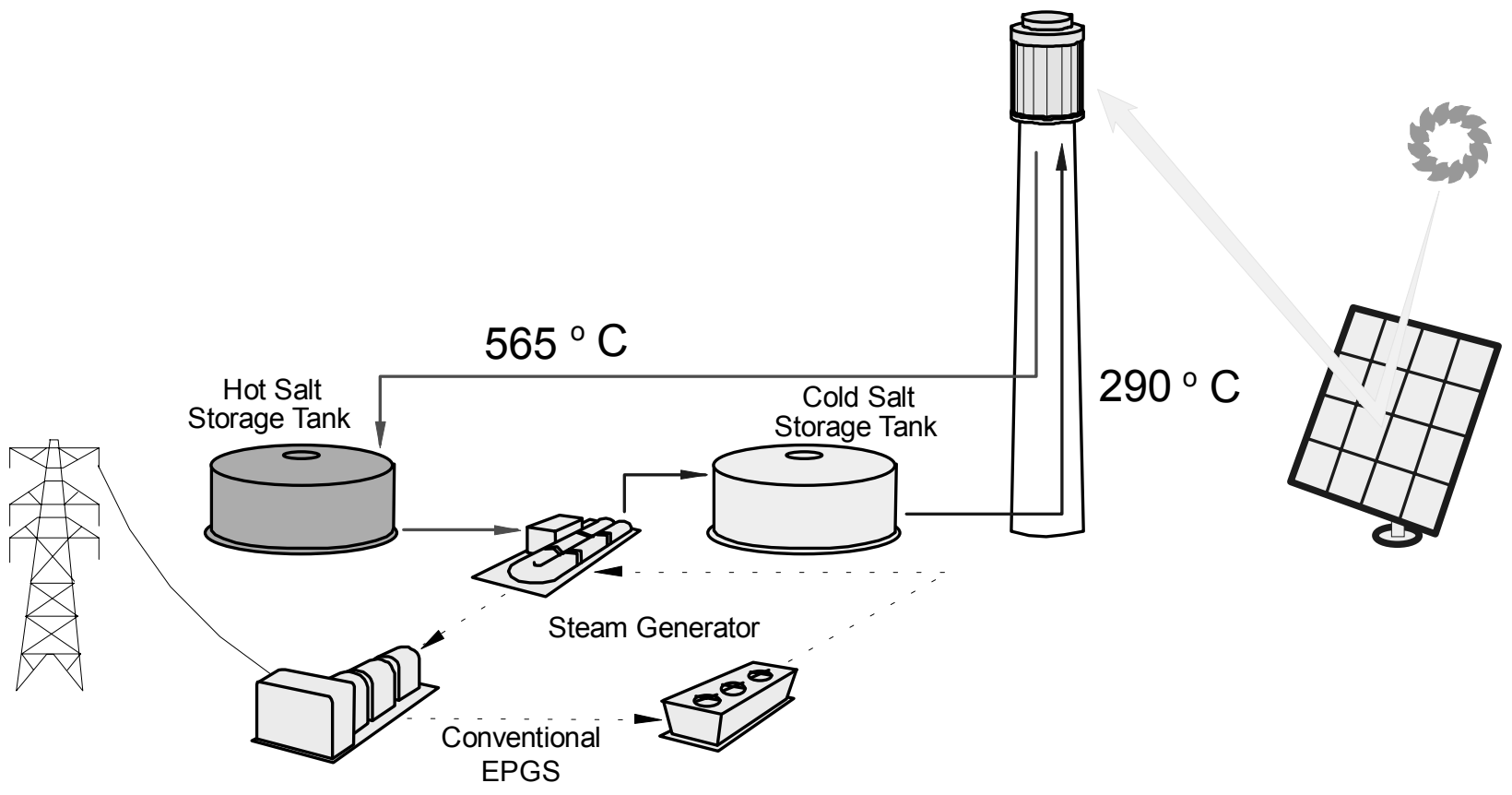

Figure 1: Schematic of a Molten-Salt Central-Receiver Power Plant 
storage system and on to the receiver to repeat the cycle. Figure 1 shows a schematic of a molten-salt central-receiver plant.

Solar Two was built in 1996 and demonstrated the viability of molten-salt technology through March 1999. From February 1997 through March 1999, Solar Two went through a thorough testing and evaluation (T\&E) routine. The T\&E activities performed at Solar Two included performance evaluation and prediction to determine and understand the plant's performance and to use the evaluation information to:

- optimize plant performance;

- extrapolate Solar Two's performance to general performance of molten-salt central-receiver technology; and

- recommend revisions to predictive models and engineering design methods for Solar Two and future-generation molten-salt technology.

This paper presents the methodology used to evaluate Solar Two's performance for four months in 1998 and the preliminary results of the evaluation.

\section{PERFORMANCE EVALUATION METHODOLOGY}

The overall approach to the performance evaluation presented in this paper is to compare the actual plant performance (both in terms of electricity generation and energy collection) to the predicted plant performance. Solar Two performance prediction was calculated using SOLERGY, a computer program (see Stoddard et al. 1987 ) that simulates the operation and power output of a solar central-receiver power plant.

The portion of the performance evaluation presented here is the lost-electricity analysis. This analysis treats the gross electricity generation predicted by the model as the ideal, design-level performance for the plant. Any difference between the design-level performance (modeled values) and the actual performance (measured values) is translated into "lost electricity." If the plant performs above the design level, the lost electricity will be negative; the loss is positive if the plant performs below the design level. Because the SOLERGY prediction is based on an ideal, design-level performance for the plant's configuration and because the Solar Two operation was not fully optimized or in full power-production mode, Solar Two's actual performance was generally (but not always) lower than SOLERGY's prediction.

The plant data of primary interest in the Solar Two lostelectricity analysis are:

- Insolation

- Wind speed

- Heliostat field cleanliness

- Heliostat field availability (\% field area tracking)

- Energy collected by the working fluid flowing through the receiver

- Energy to/from the SGS

- Gross electricity generation

- Net electricity production

The weather data and the gross electricity were metered directly at Solar Two. The actual weather data were used as input to the SOLERGY model. The energy to the working fluid and the energy to the SGS were calculated from actual plant flow and temperature data. The energy to the working fluid data were used to determine whether or not the actual solar plant thermal delivery matched the design. The energy to the SGS and the gross electricity were used together for power plant efficiency calculations.

The lost-electricity methodology breaks down the plant losses into different categories. The loss analysis begins with the energy incident on the heliostat field and tracks that energy through the plant to generated electricity. This analysis path is illustrated in the flow diagram in Figure 2.

\section{PERFORMANCE RESULTS}

For Solar Two, the results of the lost-electricity analysis are summarized in monthly plots that categorize the various causes of the lost electricity. The first of these plots is a modified waterfall plot based on the flow diagram shown in Figure 2. This plot, termed a system "effectiveness" plot, shows the ratio of the actual system efficiencies to the design system efficiencies, or other parameters when efficiencies are not applicable. Figure 3 shows a Solar Two effectiveness plot for June through October 1998 (excluding August).

The other plot used in the monthly summary of the lost electricity is a fairly detailed pie plot that apportions the loss fractions to the various causes. Figures 4-7 show

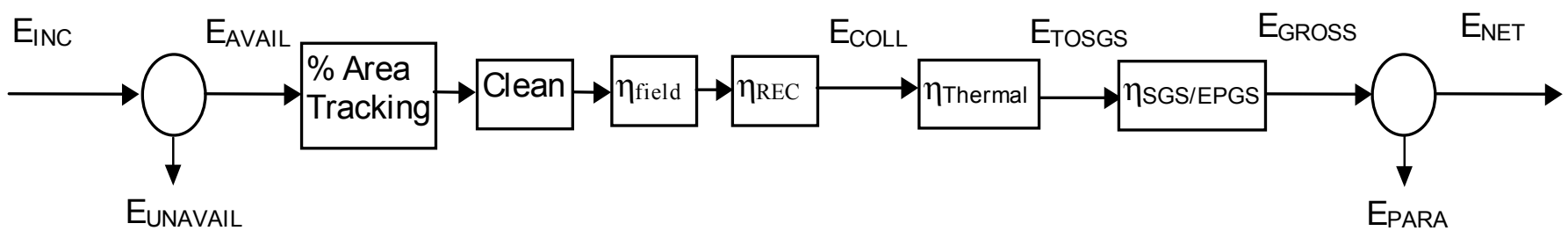

Figure 2: Energy Flow Diagram for Solar Two Lost-Electricity Analysis 


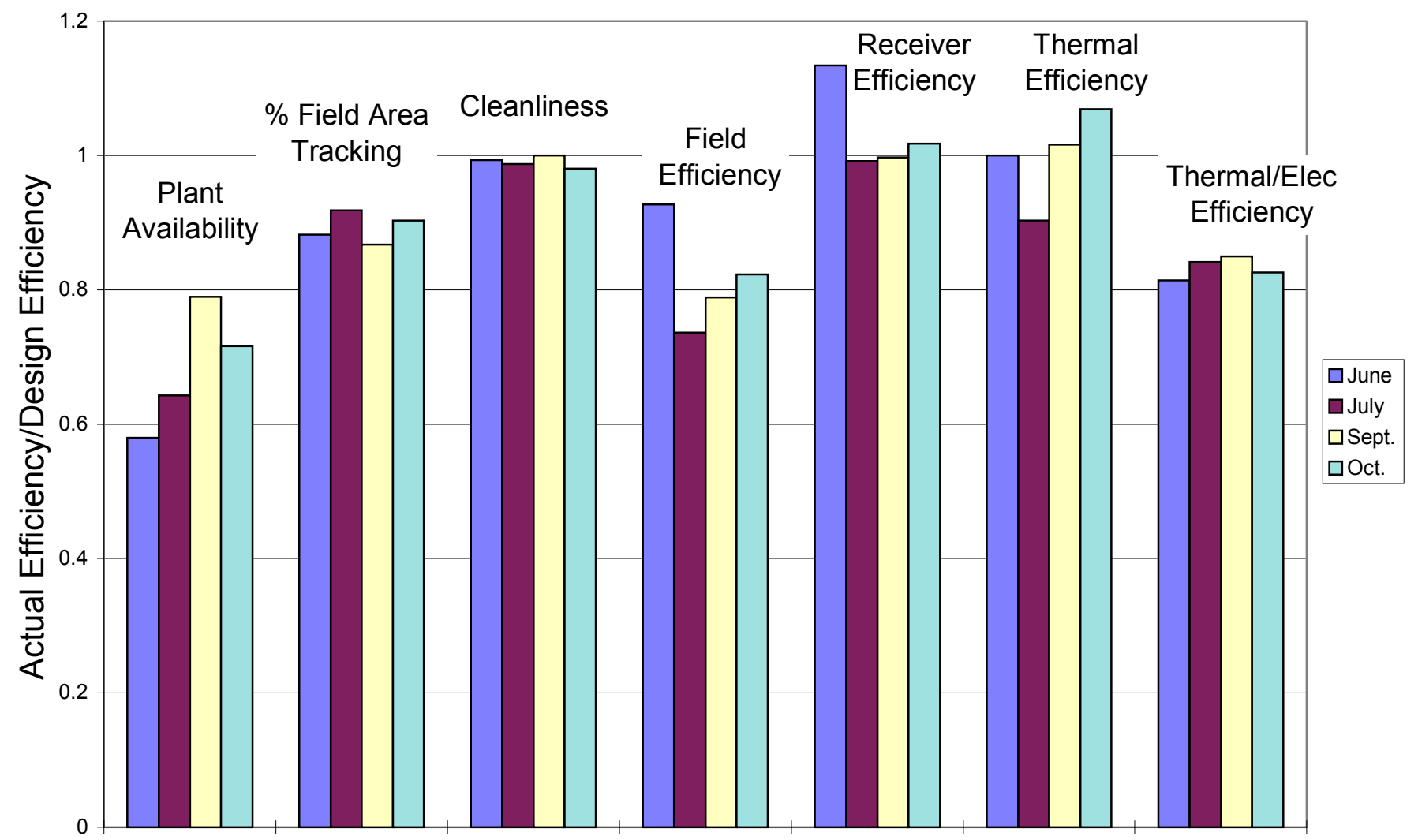

Figure 3: 1998 Solar Two Plant System Effectivenesses (Actual System Efficiency/SOLERGY System Efficiency)

the Solar Two loss contribution pie plots for June through October 1998 (again excluding August).

It should be noted that August 1998 was eliminated from these plots due to a prolonged outage.

It is readily apparent from Figures 3-7 that lower-thandesign plant availability was the leading cause for lowerthan-design Solar Two performance. The pie charts do, however, show that the loss fraction due to plant availability became smaller as time progressed. In June, availability constituted approximately $46 \%$ of the lost electricity and this fraction declined steadily to $28 \%$ in October. Figure 3 shows that plant availability became a much less significant problem as time progressed. The actual-to-design availability ratio was less than $60 \%$ in June, but above $70 \%$ by October, peaking at almost $80 \%$ in September.

The three fields "\% Field Area Tracking", "Cleanliness", and "Field Efficiency" all concern the heliostat field and, therefore, the energy reaching the receiver. Clearly, the Solar Two heliostat field did not perform as anticipated. It is a noteworthy point, however, that this was an old heliostat field (not a design that would be used in an entirely new plant) that was not designed for this receiver. For further details on the Solar Two heliostat field, see Stone and Jones (1999) and Jones and Stone (1999).

The fraction of losses attributable to low power plant efficiency varies significantly from month to month. It ranges from $32 \%$ in June to $14 \%$ in October. The power plant efficiency was dependent on plant activities (such as dispatchability tests) and how quickly the operators were able to synchronize the turbine. During June, the operators were still in the process of minimizing the energy required for the turbine start-up procedure. During June and July significant dispatchability tests were conducted during which the turbine was run at a fraction of its capacity in order to operate continuously through the night. (During July, Solar Two produced electricity continuously for 153 hours.) Figure 3 shows low power plant efficiency constitutes a fairly significant fraction-25\% - of the total losses in September. However, a comparison of the "Thermal/Electric Efficiency" bars in Figure 3 shows that the September power plant efficiency more closely approached design than did the July power plant efficiency. The explanation for this is that Solar Two experienced significantly smaller losses overall during September than during July, while the power plant efficiency losses remained somewhat level and, thus, constituted a larger portion of the overall losses. By October, not only were overall losses again minimized, but the Solar Two 


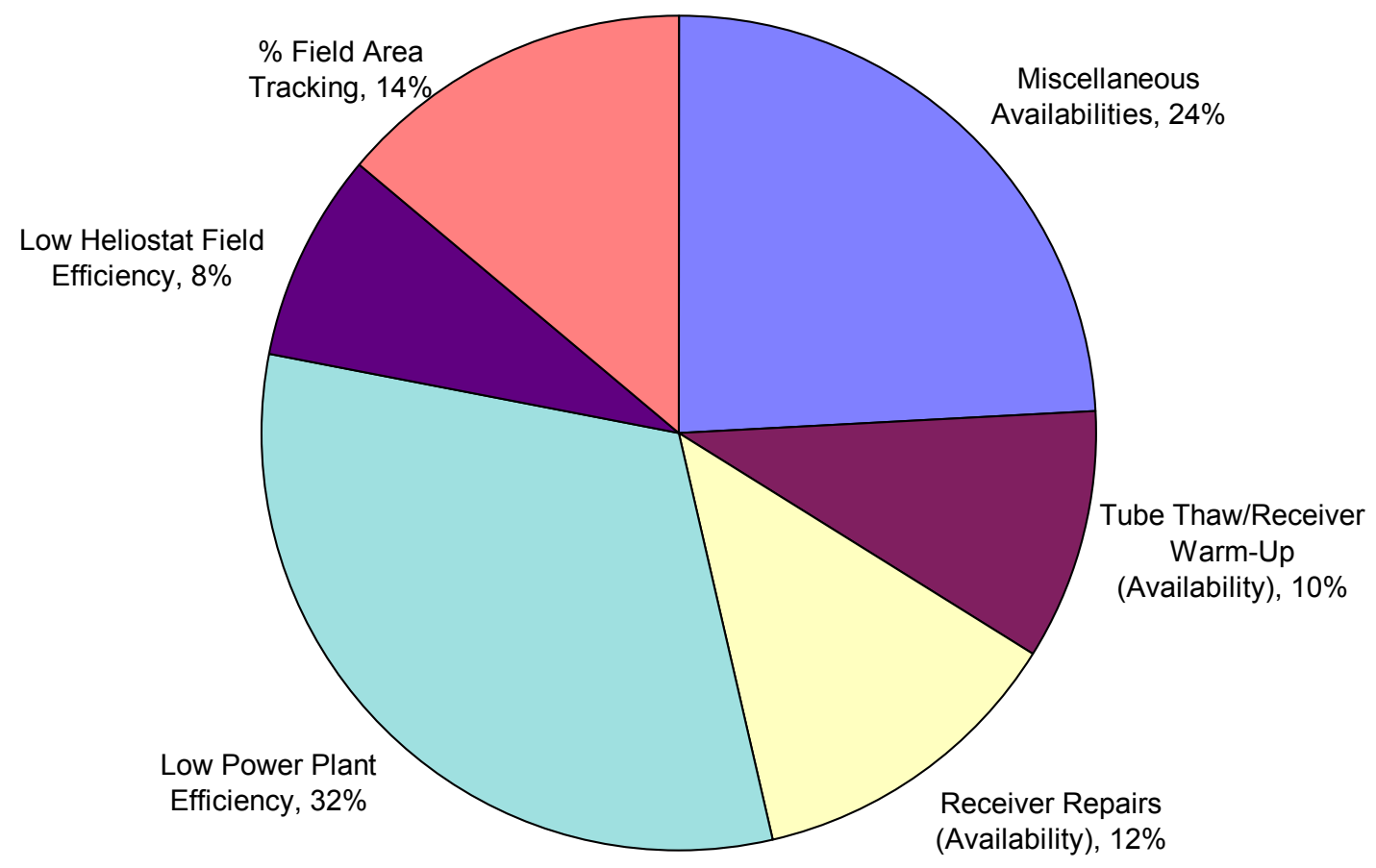

Figure 4: June 1998 Solar Two Gross Electricity Loss Contributions

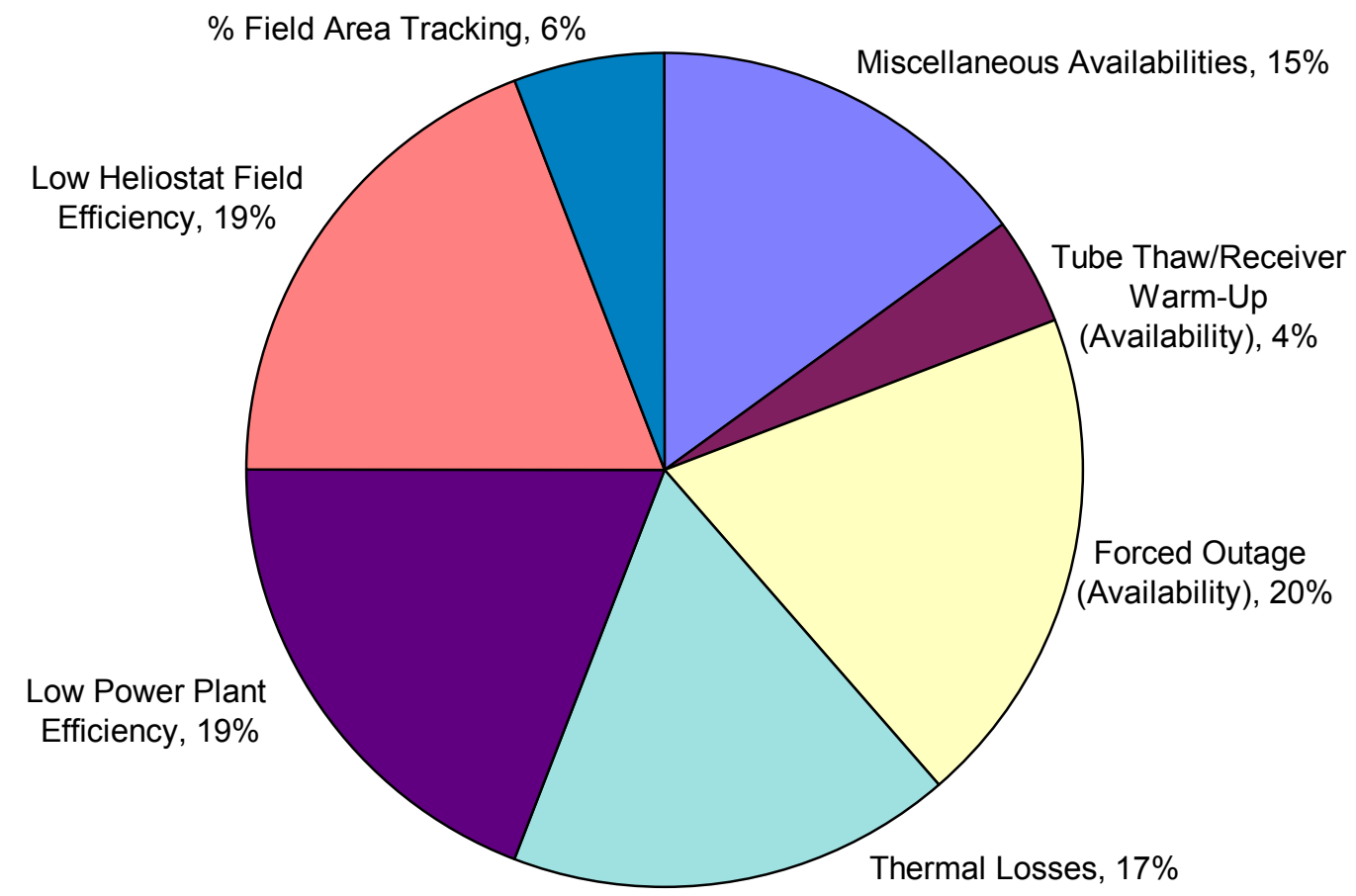

Figure 5: July 1998 Solar Two Gross Electricity Loss Contributions 
Operator Discretion (Availability), 5\%

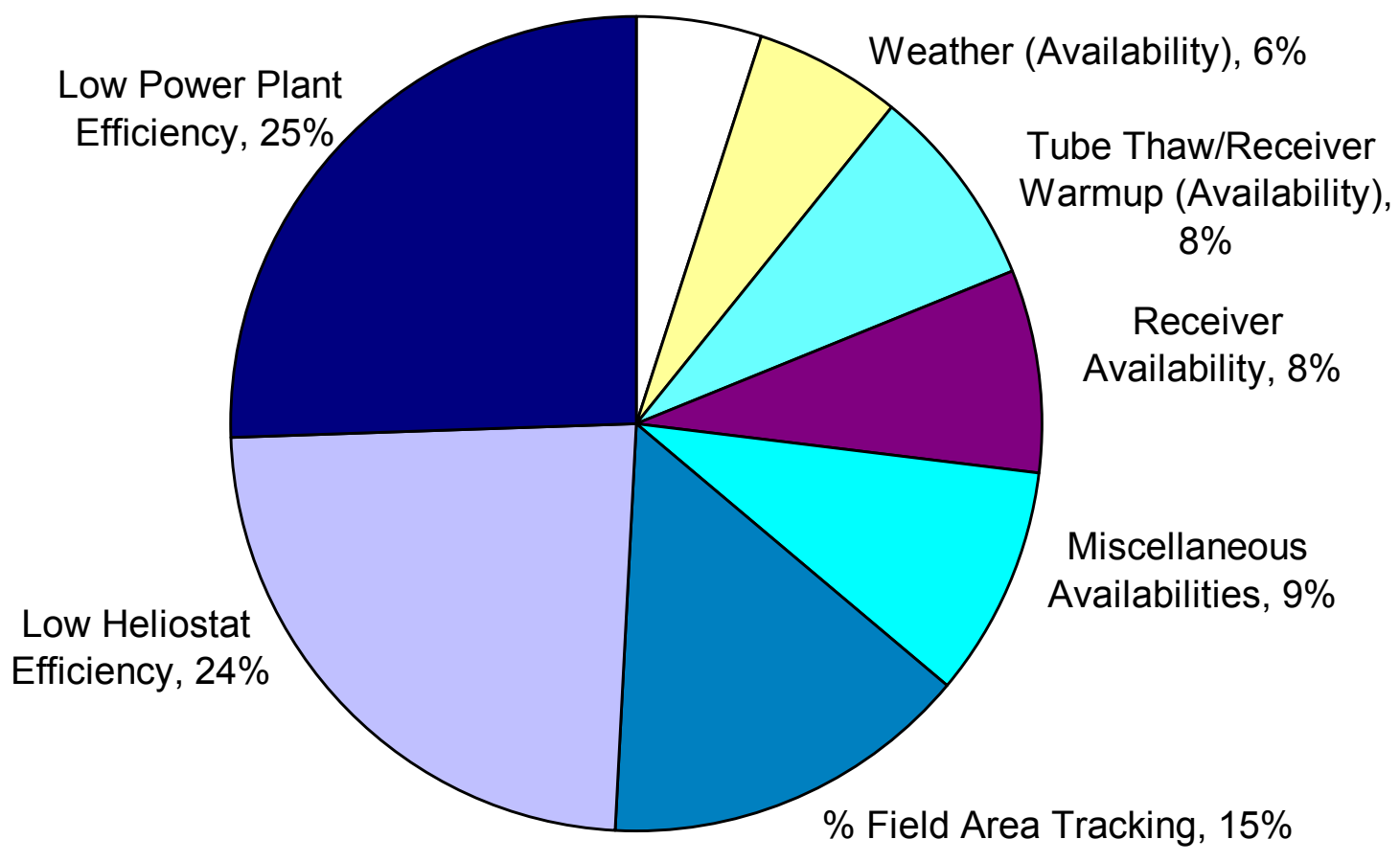

Figure 6: September 1998 Solar Two Gross Electricity Loss Contributions

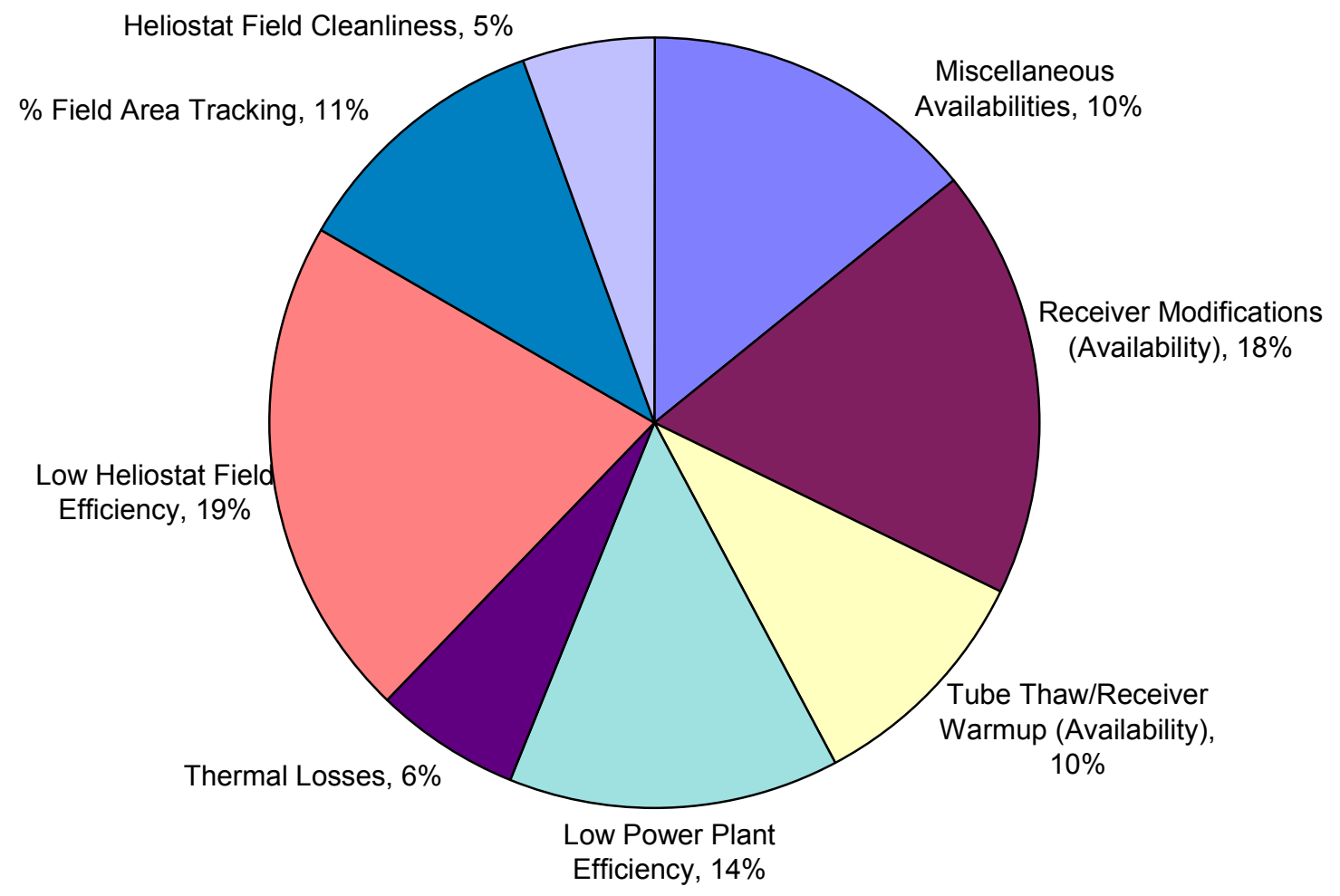

Figure 7: October 1998 Solar Two Gross Electricity Loss Contributions 
operators had developed a new procedure for minimizing the energy required to synchronize the turbine, which minimized the power-plant efficiency losses to $14 \%$ of the total.

Figures 3-7 all deal only with gross electricity generation. Obviously, the net electricity production is also a significant concern in the performance evaluation of Solar Two. For various reasons, even the predicted parasitic electric loads for Solar Two are high, on a perMWe of gross generation basis. This is due in large part to the small size of the plant and to the relatively large operations staff, which is necessary for a demonstration plant in its T\&E phase. It also is due to the lack of modern buildings (most were poorly insulated temporary structures) and the old age of much of the equipment, in particular the air conditioners (especially in a climate where evaporative cooling would easily handle the cooling load of modern computer equipment). Nevertheless, the T\&E team conducted many tests with the purpose of reducing the plant's parasitic loads. These tests ranged from determining which heat trace circuits were critical for different lengths of off-line periods to common-sense measures such as turning off all outside lights at night. Figure 8 illustrates the progress that was made toward reducing the parasitic load at Solar Two over time. It should be noted that from mid-September until the end of the project, it was not uncommon for Solar Two to "beat" the predicted parasitic load. Also, the T\&E team had a list of "Phase II" parasitic reductions (e.g., replacing outdated, remotestation air conditioners with swamp coolers), which could have been instituted but were outside the scope of this project.

\section{CONCLUSIONS}

The results of the Solar Two lost-electricity analysis show that Solar Two's availability improved much from June 1998 to October 1998, approaching 80\% of the design in September. The results also illustrate that the receiver efficiency was consistently at or above the design level. Solar Two did, however, suffer from subideal performance from the plant's older equipment, namely the heliostat field, the power generation system, controls, and building-related equipment such as air conditioners.

Much has been learned about molten-salt centralreceiver technology from Solar Two. The lost-electricity analysis has proven useful in understanding actual system performance relative to predicted performance. As the lost-electricity methodology is refined and expanded, so will be our understanding of Solar Two. We will continue to learn from Solar Two for years to come, and it will lay the groundwork for future, nextgeneration plants.

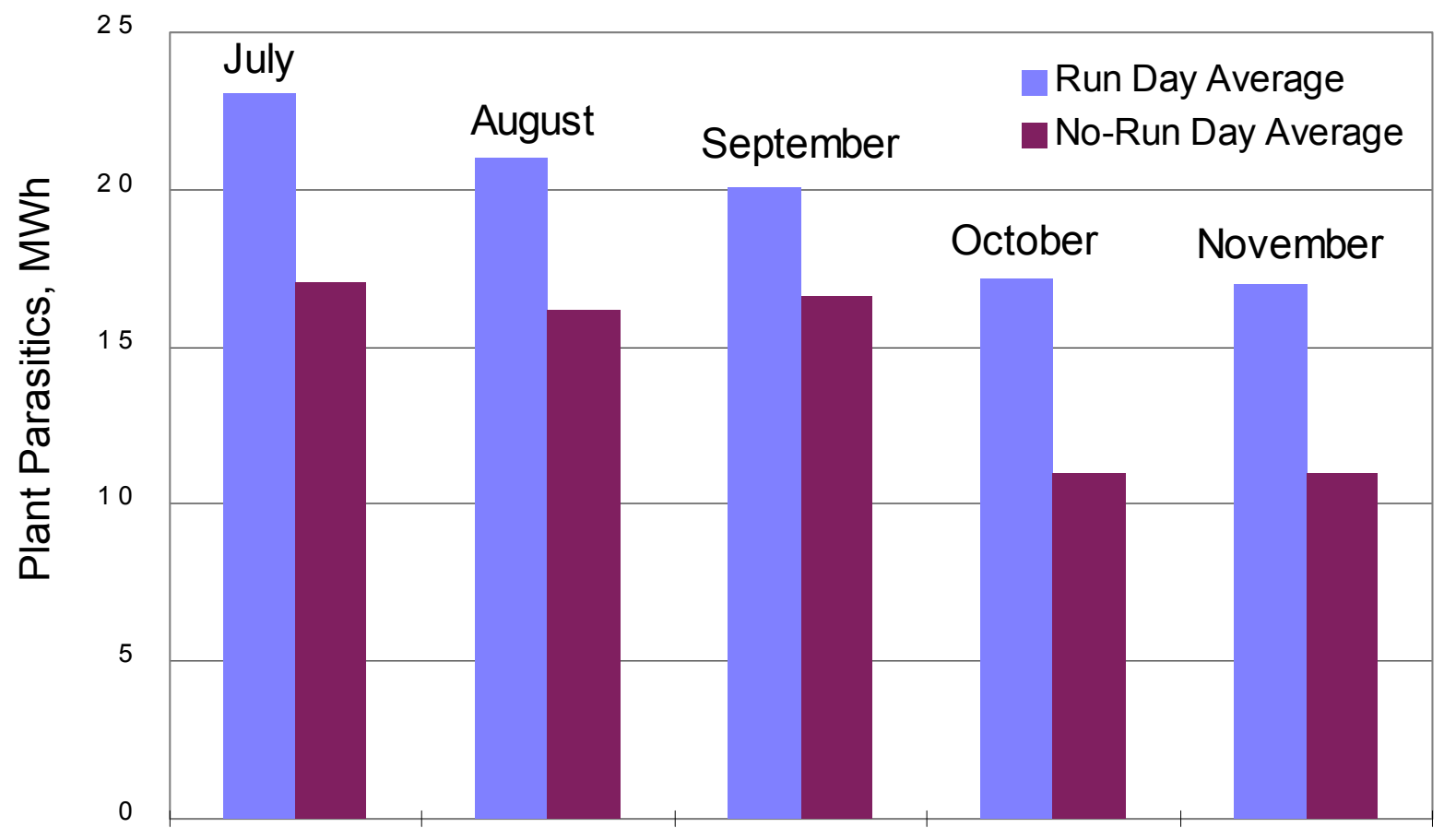

Figure 8: Average Solar Two Run Parasitics for Run and No-Run Days, July 1998 through November 1998 


\section{REFERENCES}

Analysis of Solar Two Heliostat Tracking Error Sources, K.W. Stone, S.A. Jones, Proceedings of the Renewable and Advanced Energy Systems for the $21^{\text {st }}$ Century, April 1999.

Analysis of Strategies to Improve Heliostat Tracking at Solar Two, S.A. Jones, K.W. Stone, Proceedings of the Renewable and Advanced Energy Systems for the $21^{\text {st }}$ Century, April 1999.

Estimating Convective Energy Losses from Solar Central Receivers, D. L. Stoddard, J. S. Kraabel, Report No. SAND84-8717, April 1984.

Memo from S. Faas to M.J. Hale, subject: Review of Lost Solar Electricity Analysis Methodology Handout, July 15, 1998.

SOLERGY - A Computer Code for Calculating the Annual Energy from Central Receiver Power Plants, Report No. SAND 86-8060, Stoddard et al., May 1987.

Solar Two Test and Evaluation: Program Overview and Summary of Results through 1997, J. Pacheco et al. March 1998. 
Public reporting burden for this collection of information is estimated to average 1 hour per response, including the time for reviewing instructions, searching existing data sources, gathering and maintaining the data needed, and completing and reviewing the collection of information. Send comments regarding this burden estimate or any other aspect of this

collection of information including suggestions for reducing this burden, to Washington Headquarters Services, Directorate for Information Operations and Reports, 1215 Jefferson Davis Highway, Suite 1204, Arlington, VA 22202-4302, and to the Office of Management and Budget, Paperwork Reduction Project (0704-0188), Washington, DC 20503.

\begin{tabular}{|l|l|l|l}
\hline 1. AGENCY USE ONLY (Leave blank) & $\begin{array}{l}\text { 2. REPORT DATE } \\
\text { May } 1999\end{array}$ & $\begin{array}{l}\text { 3. REPORT TYPE AND DATES COVERED } \\
\text { Conference Paper }\end{array}$ \\
\hline
\end{tabular}

\section{TITLE AND SUBTITLE}

5. FUNDING NUMBERS

Soar Two Performance Evaluation

Task \#: SE913001

6. AUTHOR(S)

Mary Jane Hale

7. PERFORMING ORGANIZATION NAME(S) AND ADDRESS(ES)

National Renewable Energy Laboratory

8. PERFORMING ORGANIZATION

1617 Cole Boulevard

Golden, CO 80401-3393

\section{SPONSORING/MONITORING AGENCY NAME(S) AND ADDRESS(ES)}

National Renewable Energy Laboratory

1617 Cole Boulevard

Golden, CO 80401-3393

\section{SUPPLEMENTARY NOTES}

\section{2a. DISTRIBUTION/AVAILABILITY STATEMENT}

National Technical Information Service

U.S. Department of Commerce

5285 Port Royal Road

Springfield, VA 22161 12b. DISTRIBUTION CODE

UC-600

13. ABSTRACT (Maximum 200 words) Solar Two was a 10-MWe prototype central receiver plant east of Barstow, California. Solar Two, which was sponsored by a consortium of utilities and industry in partnership with the U.S. Department of Energy, began regular electricity production in February 1997 and completed its last day of regular electricity production in March 1999. This paper presents preliminary results from the most recent Solar Two performance evaluation.

14. SUBJECT TERMS power tower, central receiver, Solar Two, solar energy, concentrating solar power, sunlab, csp, solar thermal electric
15. NUMBER OF PAGES

7

16. PRICE CODE
17. SECURITY CLASSIFICATION OF REPORT
18. SECURITY CLASSIFICATION OF THIS PAGE
19. SECURITY

CLASSIFICATION

OF ABSTRACT
20. LIMITATION OF ABSTRACT

Standard Form 298 (Rev. 2-89) Prescribed by ANSI Std. Z39-18 